\title{
Population-Based Screening for Rare Mutations: High-Throughput DNA Extraction and Molecular Amplification from Guthrie Cards
}

\author{
AARON HAMVAS, MICHELLE TRUSGNICH, HEATHER BRICE, JAMES BAUMGARTNER, \\ YULING HONG, LAWRENCE M. NOGEE, AND F. SESSIONS COLE
}

\begin{abstract}
Edward Mallinckrodt Department of Pediatrics, Washington University School of Medicine and St. Louis Children's Hospital [A.H., M.T., H.B., F.S.C.] and Division of Biostatistics [Y.H.], Washington University School of Medicine, St. Louis, Missouri 63110, U.S.A.; the Missouri Department of Health, Jefferson City, Missouri, U.S.A. 65102 [J.B.]; and the Department of Pediatrics, The Johns Hopkins University School of Medicine, Baltimore, Maryland 21287, U.S.A. [L.M.N.]
\end{abstract}

\begin{abstract}
To determine the population-based frequency of a rare mutation (the 121 ins 2 mutation in the surfactant protein B gene), we developed high-throughput techniques to extract reliably and rapidly amplifiable DNA from Guthrie cards. Using a 3-mm punch from each of 10,044 Guthrie cards obtained from the Missouri Department of Health, we extracted DNA with deionized water by heating in the presence of $2 \%$ Chelex in a 96 -well format. Average yield of DNA from each punch was $52.6 \pm 21$ $\mu \mathrm{g}$. Using $36 \mathrm{mer}$ primers and a $10-\mu \mathrm{L}$ reaction volume, we amplified a 354-bp fragment of the surfactant protein B gene that contained the mutation and identified the mutation by its susceptibility to restriction enzyme digestion with $S f u$ I. The procedure required $5 \mathrm{~h}$ per 96 samples but only $2 \mathrm{~h}$ of technician time. The
\end{abstract}

The availability of information about genetic variation from the Human Genome Project permits associating specific genetic variants or markers with disease phenotypes from analysis of affected individuals and families. To determine the influence of genotype on disease expression, population-based estimates of both the frequency of specific genetic variants and the disease phenotype are required. For studies of rare genetic variants, high-throughput, efficient, low-cost methods for DNA extraction and amplification are necessary to screen the number of samples necessary to achieve statistically valid estimates of allele frequency.

Inherited deficiency of SP-B is one such rare genetic cause of lethal respiratory distress syndrome in full-term newborn infants $(1,2)$. It is most commonly caused by a homozygous, frameshift, loss of function mutation in codon

Received February 16, 2001; accepted June 5, 2001.

Correspondence and reprint requests: Aaron Hamvas, M.D., Division of Newborn Medicine, St. Louis Children's Hospital, 1 Children's Place, St. Louis, MO , U.S.A.; e-mail: hamvas@kids.wustl.edu

Supported in part by a grant from the National Institutes of Health (HL/HD 54187; F.S.C.) and the Eudowood Foundation (L.M.N.). amplification rate on the first attempt was $99.2 \%$. Based on detection of eight individuals heterozygous for the mutation (confirmed by direct sequencing), we estimate the allele frequency to be $0.8 / 1000$ individuals, an estimate not significantly different from previous estimates based on independent methods. High-throughput DNA extraction and amplification will permit establishment of DNA banks as well as efficient estimation of population-based genotype frequency for both rare and common genetic disorders. (Pediatr Res 50: 666-668, 2001)

SP-B, surfactant protein B
121 of the surfactant protein B gene $(121$ ins 2$)(3,4)$. The mutation introduces an $S f u \mathrm{I}$ restriction enzyme site that permits detection of the mutation with restriction enzyme digestion. Using clinical ascertainment and molecular analysis of DNA extracted from cord blood, we previously estimated the frequency of the 121 ins 2 allele to be $1 / 1000$ individuals (95\% confidence interval, 0.03-5.6/1000) and $0.15 / 1000$ individuals (95\% confidence interval, $0.08-0.25 /$ 1000), clinical and molecular estimates, respectively (5). These estimates were limited by the accuracy of birth certificate data and by the risk of amplification of maternal DNA from cord blood samples.

Guthrie cards obtained through universal screening programs for newborn metabolic disease are an attractive source of DNA for large-scale, population-based estimates of genetic disorders (6-12). However, techniques reported to date have been labor and resource intensive and are not adapted for high throughput. We therefore developed high-throughput methods for molecular ascertainment of the frequency of the 121ins2 mutation using DNA extracted from Guthrie cards. 


\section{METHODS}

We used random, anonymous, archived Guthrie cards obtained between 1993 and 2000 by the Missouri Department of Health as part of its screening program for metabolic diseases. The unique identification number on each card permitted determination of birth certificate information for identified heterozygotes. We adapted previously described techniques for DNA extraction to enable high-throughput analysis $(6-8,13-$ 15). Specifically, we placed a 3-mm-diameter punch from each blood spot into individual wells of a 96-well polypropylene microplate (Robbins Scientific Corp., Sunnyvale, CA, U.S.A.). We flamed the paper punch between samples to avoid DNA cross-contamination (16). Each 96-well plate also contained DNA from individuals known to lack the 121 ins 2 mutation or to be homozygous or heterozygous. Because $\mathrm{Hb}$ is an inhibitor of molecular amplification, we removed $\mathrm{Hb}$ by sequential incubations with $200 \mu \mathrm{L}$ of distilled water at room temperature for $45 \mathrm{~min}$ and $30 \mathrm{~min}$ on an orbital shaker at $150 \mathrm{rpm}(17,18)$. We subsequently rinsed each well with $200 \mu \mathrm{L}$ of distilled water. $\mathrm{Hb}$ removal was more complete as judged by amplification and by color of the blood spot if this process was performed within 2 wk of punching the Guthrie card. After sealing each 96-well plate with aluminum foil and vortex mixing for $10 \mathrm{~s}$, we extracted DNA from each punch in $200 \mu \mathrm{L}$ of a solution of $2 \%(\mathrm{wt} / \mathrm{vol})$ Chelex 100 chelating resin (BioRad, Richmond, CA, U.S.A.) and 1 mM EDTA, pH 8.0. We centrifuged each plate at $500 \times g$ for $3 \mathrm{~min}$, heated each plate in a microtiter hot block to $65^{\circ} \mathrm{C}$ for $30 \mathrm{~min}$, vortex mixed, and heated to $100^{\circ} \mathrm{C}$ for $25 \min (15,19,20)$. We spectrophotometrically measured the DNA concentration in selected wells. The plates were then stored at $-20^{\circ} \mathrm{C}$ until amplification.

We performed PCR amplification in $10-\mu \mathrm{L}$ reaction volumes in each well of a 96-well plate as previously described: $5 \mu \mathrm{L}$ of supernatant containing DNA template; $1.6 \mu \mathrm{L}$ deoxynucleotides (final concentration $200 \mu \mathrm{M}$ ); $0.5 \mu \mathrm{L}$ of $5 \%$ DMSO; $0.75 \mathrm{U}(0.1 \mu \mathrm{L}) \mathrm{Taq}$ polymerase (Sigma Chemical Co., St. Louis, MO, U.S.A.), and $2 \mu \mathrm{L}$ of Buffer J $[300 \mathrm{mM}$ Tris $\mathrm{HCl}, 75 \mathrm{mM}\left(\mathrm{NH}_{4}\right)_{2} \mathrm{SO}_{4}$, and $10 \mathrm{mM} \mathrm{MgCl} 2$, Invitrogen, Carlsbad, CA, U.S.A.] (5). To increase the specificity of amplification of the target sequence, we used 36-monomer primers (sense: 5' TAA CTC CTT GGC ACT CGT GAA CTC CAG CAC CCT G 3'; antisense: 5' GCT GGC TGG GGT GCT GTG TGT GTG GCT CCC CCA TG 3') to amplify a 354-bp fragment of the SP-B gene (nucleotides 1320-1674) that contains the 121 ins 2 mutation. We amplified extracted template in a thermocycler (MJ Research, Watertown, MA, U.S.A.) as follows: $3.5 \mathrm{~min}$ at $95^{\circ} \mathrm{C}$ for initial denaturation, 30 cycles denaturation at $95^{\circ} \mathrm{C}$ for $30 \mathrm{~s}$ each, annealing at $68^{\circ} \mathrm{C}$ for $45 \mathrm{~s}$, elongation at $72^{\circ} \mathrm{C}$ for $80 \mathrm{~s}$, and a final elongation at $72^{\circ} \mathrm{C}$ for 3 min.

We performed restriction enzyme digestion with $S f u$ I as previously described $(3,5)$. Briefly, we digested amplicons in each well with $2.5 \mathrm{U}(5 \mu \mathrm{L}) \mathrm{Sfu}$ I in H buffer (Roche Molecular Biochemicals, Indianapolis, IN, U.S.A.) by incubating at $37^{\circ} \mathrm{C}$ for $90 \mathrm{~min}$. We added $5 \mu \mathrm{L}$ of loading buffer and subjected each digest to metaphor/agarose-ethidium bromide gel electrophoresis. Each gel was photographed under UV light and scanned into a database. Heterozygotes were identified by inspection of the gel. The identification number on the Guthrie card was forwarded to the Missouri State Department of Health, where one of us (J.B.) extracted the demographic data from the birth certificate database. No one investigator had access to all the information.

The Washington University School of Medicine Human Subjects Committee approved this study.

\section{RESULTS}

We found that increasing the time of the second incubation during DNA extraction increased the DNA yield from each blood spot significantly: in 24 samples, the DNA yield after 10 min of incubation at $100^{\circ} \mathrm{C}$ was $30.8 \pm 10 \mu \mathrm{g}$, and after 25 $\min , 52.6 \pm 21 \mu \mathrm{g}(p<0.001$ by paired $t$ test $)$. The DNA was reliably amplifiable: only 174 of $10,044(1.7 \%)$ failed to amplify on the first attempt. After a second attempt, 172 of the 174 samples successfully amplified, for an overall amplification success rate $>99.9 \%$. The oldest Guthrie card from which DNA was successfully amplified was 6 y old. Extraction from and amplification of each 96-well plate required $5 \mathrm{~h}$, but only $2 \mathrm{~h}$ of technician time. We estimate the cost of the reagents for these analyses to be approximately 35 cents per sample.

We identified eight samples heterozygous for the 121 ins2 mutation (Fig. 1), which were confirmed by direct sequencing. We therefore estimated a gene frequency in this population of $0.8 / 1000$ individuals $(95 \%$ confidence interval, $0.2 / 1000-1.4 /$ 1000 ), an estimate not significantly different from the previous molecular estimate from New York City and clinical estimate from Missouri (0.3/1000 and 1/1000, respectively, $p=0.3$ by Fisher's exact test) (5). There were six male and two female infants; seven were white and one was black; all had normal birth weights. Respiratory distress syndrome was not noted in the birth certificate information of these eight infants.

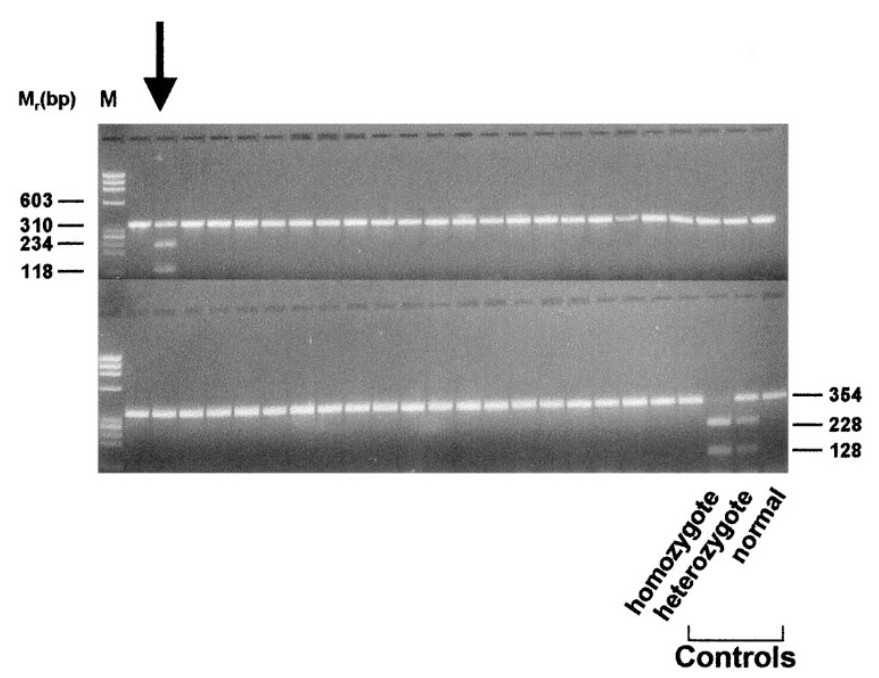

Figure 1. Representative $S f u$ I digest for the 121 ins 2 mutation in DNA amplified from Guthrie cards. Pictured is a gel with 48 of the 96 wells from one microplate. Each lane contains amplified DNA from one individual. Lanes with normal, heterozygous, and homozygous controls are labeled. One subject heterozygous for the 121 ins 2 mutation is identified on this plate (arrow). 


\section{DISCUSSION}

Statistically valid estimates of the frequency of rare alleles require screening of large populations. Availability of previous estimates of the frequency of the most common mutation that causes SP-B deficiency (121ins2) provided the opportunity to test the validity and throughput characteristics of methods for DNA extraction and amplification from Guthrie cards (5). Potential amplification of maternal DNA in cord blood samples and under-ascertainment of affected infants from birth certificate data limited the usefulness of methods used for previous estimates. Guthrie cards obtained from state-based neonatal screening programs provide a potentially useful source for population-based screening: demographics of the population can be obtained from birth certificates (with appropriate protections for confidentiality), the sample is not biased by clinical or institutional variables, and the likelihood of maternal DNA contamination in samples obtained at $2-3 \mathrm{~d}$ of life is low. Previous methods for DNA extraction and amplification from Guthrie cards have been limited by lack of high-throughput capability (6-15). In this analysis of the largest sample population to date, we report that adequate amounts of DNA for multiple determinations can be extracted from a single 3-mm punch and that inhibitors of molecular amplification, including $\mathrm{Hb}$, albumin, and heavy metals, can be adsorbed with $2 \%$ Chelex. The time required for these methods (approximately $5 \mathrm{~h}$ per 96 samples) permits a single technician with access to two thermocyclers to process up to 1000 samples per week.

The lack of statistical difference between the estimate of the 121 ins 2 gene frequency in this report and our previous report may be related to the limited statistical power of our study, but also suggests that this high-throughput method provided a reasonable estimate of this rare allele. Additional studies evaluating the 25,000 samples necessary to detect confidently differences in this and other rare alleles between populations are underway. Because the 121ins 2 mutation accounts for approximately two thirds of the mutant alleles responsible for SP-B deficiency, we can extrapolate our estimate to suggest that SP-B deficiency occurs with a frequency of approximately 1 in 2 million births in the United States (4). Regional differences in ethnic distribution may contribute to differences in apparent disease frequency. From the birth certificate diagnoses, which historically have been limited in the ability to detect clinical conditions of the newborn, the infants in this cohort heterozygous for 121 ins 2 did not exhibit respiratory symptoms at birth, which is consistent with previous observations $(2,3,21,22)$.

The small reaction volume for molecular amplification (10 $\mu \mathrm{L}$ ), the simplicity of reagents for DNA extraction, the low average technician time ( 3 min per sample), and the quality of the extracted DNA make these methods attractive for the development of DNA banks for use in determination of the population-based frequency of genetic variants (23). Detection systems that use DNA chip-array technology may be more cost-effective and efficient than restriction enzyme digestion for identification of new or known mutations.

Acknowledgments. The authors thank Corrine Hamvas, Jennifer Heeley, Robert Jones, Qua Mei Lei, Robin Peterson, George Roffman, Thomas Sandbothe, and Jasmine Wong for technical assistance.

\section{REFERENCES}

1. Nogee LM, deMello DE, Dehner LP, Colten HR 1993 Brief report: deficiency of pulmonary surfactant protein B in congenital alveolar proteinosis. N Engl J Med 328:406-410

2. Hamvas A 1997 Surfactant protein B deficiency: insights into inherited disorders of lung cell metabolism. Curr Probl Pediatr 27:325-352

3. Nogee LM, Garnier G, Singer L, Dietz HC, Murphy AM, Cutting GR, deMello DE, Colten HR 1994 A mutation in the surfactant protein B gene responsible for fatal neonatal respiratory disease in multiple kindreds. J Clin Invest 93:1860-1863

4. Nogee LM, Wert SE, Proffit SA, Hull WM, Whitsett JA 2000 Allelic heterogeneity in heredity surfactant protein B (SP-B) deficiency. Am J Respir Crit Care Med 161:973-981

5. Cole FS, Hamvas A, Rubinstein P, King E, Trusgnich M, Nogee LM, deMello DE, Colten HR 2000 Population-based estimates of a rare genetic disease of infancy: surfactant protein B deficiency. Pediatrics 105:538-541

6. Schwartz EI, Khalchitsky SE, Eisensmith RC, Woo SLC 1990 Polymerase chain reaction amplification from dried blood spots on Guthrie cards. Lancet 336:639-640

7. Nelson PV, Carey WF, Morris CP 1990 Gene amplification directly from Guthrie blood spots. Lancet 336:1451-1452

8. McCabe ERB 1991 Utility of PCR for DNA analysis from dried blood spots on filter paper blotters. PCR Methods Appl 1:99-106

9. Seddon HR, Gray G, Pollitt RJ, Iitia A, Green A 1997 Population screening for the common G985 mutation causing medium-chain acyl-CoA dehydrogenase deficiency with EU-labeled oligonucleotides and the DELFIA system. Clin Chem 43:436-438

10. Makowski GS, Hopfer SM 1998 Cystic fibrosis: molecular approaches to diagnosis. Ann Clin Lab Sci 28:380-385

11. Den Boer MEJ, Ijlst L, Wijburg FA, Oostheim W, Van Werkhoven MA, Van Pampus MG, Heymans HAS, Wanders RJA 2000 Heterozygosity for the common LCHAD mutation $(1528 \mathrm{G} \rightarrow \mathrm{C})$ is not a major cause of HELLP syndrome and the prevalence of the mutation in the Dutch population is low. Pediatr Res 48:151-154

12. Gasparini, Arbustini E, Restagno G, Zelante L, Stanziale P, Gatta L, Sbaiz L, Sedita AM, BanchSapone L, Fiorucci GC, Brinson E, Shulse E, Rappaport E, Fortina P 1999 Analysis of 31 CFTR mutations by polymerase chain reaction/oligonucleotide ligation assay in a pilot screening of 4476 newborns for cystic fibrosis. J Med Screen 6:67-69

13. Carducci C, Ellul L, Pontecorvi A, Pontecorvi A 1992 DNA elution and amplification by polymerase chain reaction from dried blood spots. Biotechniques 15:735-737

14. Schneeberger C, Kury F, Larsen J, Speiser P, Zeillinger R 1992 A simple method for extraction of DNA from Guthrie cards. PCR Methods Appl 2:177-179

15. Polski JM, Kimzey S, Percival RW, Grosso LE 1998 Rapid and effective processing of blood specimens for diagnostic PCR using filter paper and Chelex-100. Mol Pathol 51:215-217

16. Del Rio SA, Marion MA, Belgrader P 1996 Reusing the same blood-stained punch for sequential DNA amplifications and typing. Biotechniques 20:970-974

17. Makowski GS, Davis EL, Hopfer SM 1997 Amplification of Guthrie card DNA: effect of guanidine thiocyanate on binding of natural whole blood PCR inhibitors. J Clin Lab Anal 11:87-93

18. Akane A, Matsubara K, Nakamura H, Takahashi S, Kimura K 1994 Identification of the heme compound copurified with deoxyribonucleic acid (DNA) from bloodstains, a major inhibitor of polymerase chain reaction (PCR) amplification. J Forensic Sci 39:362-372

19. Walsh PS, Metzger DA, Higuchi R 1991 Chelex 100 as a medium for simple extraction of DNA for PCR-based typing from forensic material. Biotechniques 10:506-513

20. Singer-Sam J, Tanguay RL, Riggs AD 1989 Use of Chelex to improve the PCR signal from a small number of cells. Amplifications: A Forum for PCR Users 3:11

21. Hamvas A, Kwong P, DeBaun M, Schramm W, Cole FS 1998 Hyaline membrane disease is underreported in a linked birth-infant death certificate database. Am J Public Health 88:1387-1389

22. Yusen RD, Cohen AH, Hamvas A 1999 Normal lung function in subjects heterozygous for surfactant protein B deficiency. Am J Respir Crit Care Med 159:411-414

23. McEwen JE, Reilly PR 1994 Stored Guthrie cards as DNA “banks." Am J Hum Genet 55:196-200 